\title{
APLIKASI LOCATION BASED SERVICE "TOLONG.IN" PADA PLATFORM ANDROID
}

\author{
${ }^{1}$ Irene Anindaputri Iswanto, ${ }^{2}$ Kevin Wahyu Triwaldi, ${ }^{3}$ Bosta Harry Hagata $G,{ }^{4}$ Dhana \\ Firmansyah \\ Computer Science Department, School of Computer Science \\ Bina Nusantara University - Jakarta, 11480, Indonesia \\ e-mail : ${ }^{1}$ irene.iswanto@binus.edu, ${ }^{2}$ kevincrash20@gmail.com, ${ }^{3}$ bosta.ginting@gmail.com, \\ domdooom10@gmail.com.
}

\begin{abstract}
ABSTRAKSI
Manusia diciptakan sebagai makhluk sosial, yang berarti manusia tidak dapat hidup tanpa sesamanya. Sifat makhluk sosial yang dimiliki oleh manusia ini mendorong manusia untuk memiliki sikap tolong menolong. Sikap tolong-menolong ini mengilhami masyarakat untuk menggunakannya sebagai sumber penghasilan. Namun peluang bisnis dari penawaran jasa ini kurang didukung oleh media informasi yang memadai. Tidak adanya media yang secara khusus diciptakan untuk kegiatan transaksi jasa ini membuat para penyedia jasa kesulitan dalam memasarkan jasanya. Tidak adanya media informasi ini juga menyulitkan pencari jasa untuk memperoleh informasi mengenai penyedia jasa yang mereka butuhkan. Penggunaan sosial media untuk transaksi jasa dirasa kurang aman karena tidak adanya sistem verifikasi mengenai kredibilitas sang penyedia jasa. Semakin meningkatnya teknologi smartphone semakin memberi kemudahan pada kehidupan masyarakat. Adanya teknologi GPS (Global Positioning System) membuat para developer menggunakannya untuk membuat aplikasi Location Based Service yang menggunakan informasi dari posisi user untuk menawarkan berbagai jasa. Oleh karena itu, untuk memfasilitasi para penyedia dan pencari jasa, penulis membuat aplikasi mobile location based service pada platform android yang dapat digunakan sebagai media pemasaran penyedia jasa dan informasi mengenai penyedia jasa terdekat. Aplikasi ini juga digunakan untuk memudahkan komunikasi antara pencari dan penyedia jasa, serta menjaga keamanan transaksi dengan adanya sistem pemberian rating.
\end{abstract}

Kata kunci : Location Based Service, Global Positioning System, Android Based Application, Service provider, Java. 


\section{PENDAHULUAN}

\subsection{Latar Belakang}

Manusia diciptakan sebagai makhluk sosial, yang berarti manusia tidak dapat hidup tanpa sesamanya. Sifat makhluk sosial yang dimiliki oleh manusia ini mendorong manusia untuk memiliki sikap tolong menolong. Tingkah laku menolong dalam psikologi sosial dikenal dengan tingkah laku prososial, yaitu tindakan menolong orang lain tanpa adanya keuntungan langsung bagi si penolong (Baron, 2006 ). Masyarakat membutuhkan satu sama lain sebagai makhluk sosial dimana perilaku menolong merupakan kunci utama dalam membangun sifat kekeluargaan dalam bentuk permasalahan apapun.

Sikap tolong-menolong ini mengilhami masyarakat untuk menggunakannya sebagai sumber penghasilan. Masyarakat menyadari bahwa semakin banyak orang yang membutuhkan pertolongan atau jasa dari orang lain sehingga mereka menggunakan peluang ini untuk meningkatkan perekonomiannya. Saat ini apa saja bakat dan kapabilitas masyarakat dapat dijadikan peluang untuk menghasilkan uang, salah satunya dengan membuka jasa dengan bermodalkan keterampilan dan keuletan dari yang masyarakat tersebut miliki.

Namun peluang bisnis dari penawaran jasa yang diciptakan masyarakat Indonesia ini kurang didukung oleh media informasi yang memadai. Saat ini di Indonesia belum ada wadah informasi yang dapat digunakan oleh para pencari jasa yang kesulitan memasarkan keterampilan mereka. Penyedia jasa di Indonesia masih memanfaatkan media sosial untuk memasarkan jasa mereka di mana cara ini masih dinilai kurang efektif karena sosial media yang ada memang tidak ditujukan secara khusus untuk penawaran jasa. Selain itu tidak adanya sistem yang dapat memberikan rekomendasi mengenai penyedia jasa yang dapat dipercaya juga membuat transaksi menjadi kurang aman. Masyarakat sebagai pencari jasa juga membutuhkan wadah di mana mereka bisa mencari dengan mudah jasa yang mereka butuhkan secara cepat dan aman.

Dewasa ini, teknologi informasi dan komunikasi berkembang sangat pesat, terutama pada mobile phone. Diciptakannya smartphone membuat penyebaran informasi menjadi lebih cepat dan mudah. Selain itu diciptakannya aplikasi-aplikasi pada smartphone banyak membantu memudahkan kehidupan manusia. Salah satu teknologi pada smartphone yang banyak digunakan untuk membantu kehidupan manusia adalah Global Positioning System (GPS). Dengan menggunakan GPS manusia bisa mengetahui lokasi keberadaannya secara real time.

Location Based Service(LBS) adalah sistem yang menggunakan GPS dalam pengaplikasiannya. Dengan menggunakan GPS, LBS tidak hanya mengetahui posisi pengguna namun juga dapat memberikan informasi mengenai lokasi-lokasi tertentu, sehingga melalui aplikasi LBS ini pengguna akan mengetahui rute dari posisi pengguna sampai ke lokasi tempat tertentu.
Untuk mendukung kegiatan tolongmenolong serta menjadi media informasi bagi para penyedia jasa dan pencari jasa, penulis membuat suatu aplikasi Location Based Service bernama "tolong.in" yang menggunakan teknologi GPS. Teknologi GPS pada aplikasi ini digunakan untuk mengetahui posisi penyedia jasa yang terdekat dengan pencari jasa serta memberikan rute kepada penyedia jasa untuk bisa sampai kepada lokasi pencari jasa. Aplikasi "tolong.in" ini juga akan dilengkapi dengan sistem rating yang dapat memverifikasi performa setiap penyedia jasa dan dapat memberikan rekomendasi mengenai penyedia jasa yang dapat dipercaya kepada para pencari jasa. Diharapkan melalui aplikasi "tolong.in" ini transaksi penawaran dan pembelian jasa dapat berlangsung dengan lebih cepat, mudah, dan aman.

\subsection{Tujuan}

Tujuan yang ingin dicapai dalam penelitian ini adalah :

(1) Merancang dan mengembangkan aplikasi yang dapat memudahkan penggunanya untuk memasarkan jasa dan keahliannya.

(2) Merancang dan mengembangkan aplikasi yang dapat memberikan informasi mengenai jasa yang diinginkan oleh para pencari jasa.

(3) Merancang dan mengembangkan aplikasi yang dapat dijadikan sebagai media antara pencari dan penyedia jasa yang dilengkapi oleh fitur pin location yang berguna untuk mengetahui lokasi dari request yang dibuat oleh pencari jasa.

(4) Merancang dan mengembangkan aplikasi yang dapat menjadi media untuk bertukar informasi secara real-time antara customer dan penyedia jasa.

\section{KAJIAN PUSTAKA}

\subsection{Location Based Service}

Location Based Service adalah suatu layanan yang berbasiskan pada posisi geografi suatu lokasi. Menggunakan teknologi Location Based Service memungkinkan pengguna untuk mencari lokasi dari tempat-tempat yang terdekat seperti ATM terdekat, hotel terdekat, SPBU terdekat, dan juga alamat dari suatu tempat. (Yulianto, 2010)

Menurut Badrul Anwar et al. terdapat 4 komponen pendukung utama dalam Location Based Service, yaitu :

(1) Piranti Mobile

Piranti mobile berfungsi sebagai media untuk meminta informasi. Informasi yang didapatkan dapat berupa teks, suara, dan gambar.

(2) Jaringan Komunikasi

Jaringan komunikasi berfungsi sebagai penghubung antara pengguna dan penyedia layanan. Melalui jaringan komunikasi data-data 
yang diinputkan oleh pengguna dapat dikirimkan ke penyedia layanan untuk selanjutnya penyedia layanan mengirim kembali hasil permintaan kepada pengguna.

(3) Komponen Positioning (Penunjuk posisi) Pada aplikasi Location Based Service, mendapatkan posisi geografis pengguna biasanya adalah kunci utama dari setiap penyedia jasa. Oleh karena itu dibutuhkan teknologi yang dapat mengetahui secara akurat posisi pengguna. Teknologi yang biasa digunakan adalah Global Positioning System (GPS)

(4) Penyedia layanan dan konten (Service and content provider)

Penyedia layanan merupakan komponen dari Location Based System yang memberikan berbagai layanan kepada pengguna.

Aplikasi pencarian tempat di kota manado berbasis android (B. R. Rompas, 2012) adalah salah satu aplikasi Location Based Service yang memanfaatkan teknologi GPS untuk memberi tahu lokasi fasilitas publik terdekat yang ada di kota Manado seperti hotel, restoran, SPBU, dan rumah sakit. Tidak hanya memberikan informasi mengenai lokasi terdekat namun juga rute bagaimana pengguna dapat mencapai lokasi fasilitas publik tersebut.

Contoh lain dari aplikasi Location Based Service adalah aplikasi pencarian lokasi wisata berbasis android yang dibuat oleh M. Abdurrozzaq Almuzakki (Almuzakki, 2013). Ide pembuatan aplikasi ini berawal sulitnya para wisatawan Semarang menemukan berbagai lokasi wisata di kota Semarang. Untuk itu Almuzakki membuat aplikasi layanan berbasis lokasi yang dapat memberikan informasi rute secara detail kepada pengguna / wisatawan yang ingin berkunjung ke obyek-obyek wisata di Semarang.

\subsection{Global Positioning System}

Wishnu (Wishnu, 2012) menjelaskan Global Positioning System (GPS) sebagai sistem navigasi yang menggunakan teknologi satelit. Satelit yang digunakan, mengirimkan gelombang mikro ke bumi. Selanjutnya sinyal ini akan diterima oleh receiver. Beberapa informasi yang diterima oleh GPS Receiver antara lain adalah :

(1) Waktu

(2) Lokasi.

Informasi lokasi yang diberikan adalah dalam 3 dimensi, yaitu : latitude, longitude, dan elevasi

(3) Kecepatan.

(4) Arah perjalanan

(5) History lokasi yang pernah dikunjungi

(6) Komulasi data.

Komulasi data adalah semua informasi yang diterima oleh GPS tracker seperti kecepatan rata-rata, riwayat perjalanan yang telah dilakukan, waktu actual sampai tujuan, dan sebagainya.

\subsection{Android}

Android adalah sistem operasi yang ada pada smartphone yang berbasis Linux. Android menyediakan platform terbuka untuk semua pengembang aplikasi untuk menciptakan aplikasi mereka sendiri untuk digunakan oleh berbagai macam mobile device (Buulolo, 2013). Android menyediakan semua tools dan frameworks secara lengkap yang digunakan untuk pengembangan aplikasi pada suatu mobile device.

Platform android terdiri dari Sistem Operasi berbasis Linux, sebuah GUI (Graphic User Interface),sebuah web browser dan Aplikasi EndUser yang dapat di download dan juga para pengembang bisa dengan leluasa berkarya serta menciptakan aplikasi yang terbaik dan terbuka untuk digunakan oleh berbagai macam perangkat.

\section{ANALISA DAN RANCANGAN}

\subsection{Metode Perancangan Program}

Metode perancangan program yang digunakan adalah metode waterfall yang digambarkan dalam gambar 1 .

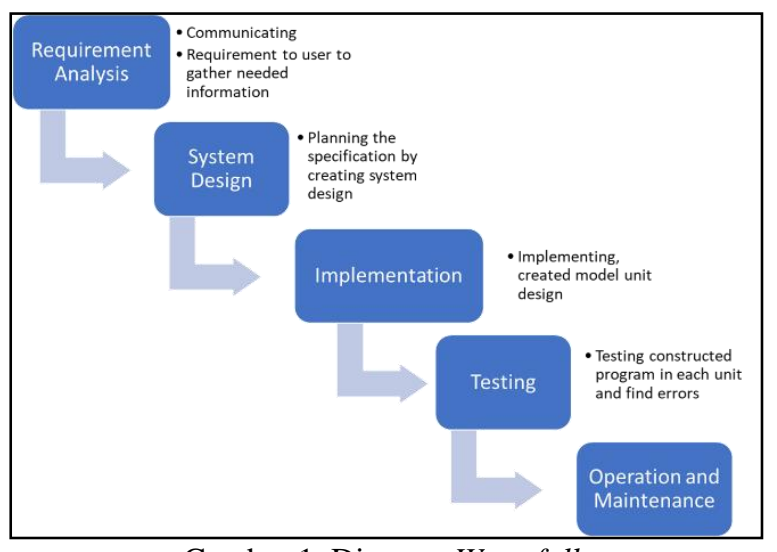

Gambar 1. Diagram Waterfall

Berikut adalah penjelasan dari masing-masing tahapan di atas.

\section{(1) Requirement Analysis}

Pada tahapan ini penulis menetapkan requirement yang diperlukan untuk menunjang aplikasi yang dibuat. Hasil pengumpulan requirement digunakan untuk menunjang pengembangan aplikasi salah satunya adalah untuk menentukan fitur-fitur apa saja yang sebaiknya ada dalam aplikasi. Metode pengumpulan data yang digunakan adalah penyebaran kuesioner secara online.

(2) System Design 
Pada tahapan System Design penulis mulai membuat system desain sesuai dengan requirement yang telah kami tetapkan di awal. Proses desain dimulai dengan membuat rancangan User Interface (UI) dan perancangan system. Pembuatan desain ini meliputi perancangan layer yang mengacu pada 8 Golden Rules of Interface Design yang bertujuan untuk memberi tampilan yang memukau dan user friendly. Selain itu penulis juga merancang back-end system untuk aplikasi Tolong.in dengan menggunakan NoSQL yang didukung dengan teknologi Firebase. Selain itu pembuatan Unified Modelling Language (UML) diterapkan. Dimulai dari membuat Use Case diagram, Activity Diagram, Class Diagram, dan Sequence Diagram.

(3) Implementation

Pada tahapan ini penulis mengimplementasi dan menerapkan seluruh rancangan desain yang telah didesain menjadi sebuah program. Android studio digunakan untuk dalam tahap implementasi ini.

\section{(4) Testing}

Setelah coding selesai maka pada tahapan ini dilakukan uji coba atau testing dari aplikasi mobile yang telah diselesaikan. Aplikasi akan diuji coba oleh beberapa user. Proses Testing aplikasi Tolong.in diawali dengan memeriksa seluruh fitur dari aplikasi berjalan dengan baik. Setelah semua berjalan dengan baik, maka dapat dipastikan bahwa aplikasi siap untuk digunakan oleh user.

(5) Operation and maintenance

Disinilah tahap akhir dari waterfall model dimana seluruh aplikasi yang telah di test akan dioperasikan dan di publish. Ditahap inilah pengembangan dan pengujian berakhir dan software yang selesai dapat digunakan dan dioperasikan oleh user dan pihak provider dapat melakukan maintenance terhadap aplikasi yang telah dikembangkan.

\subsection{Use Case Diagram}

Use Case aplikasi “tolong.in"dapat dilihat pada Gambar 2

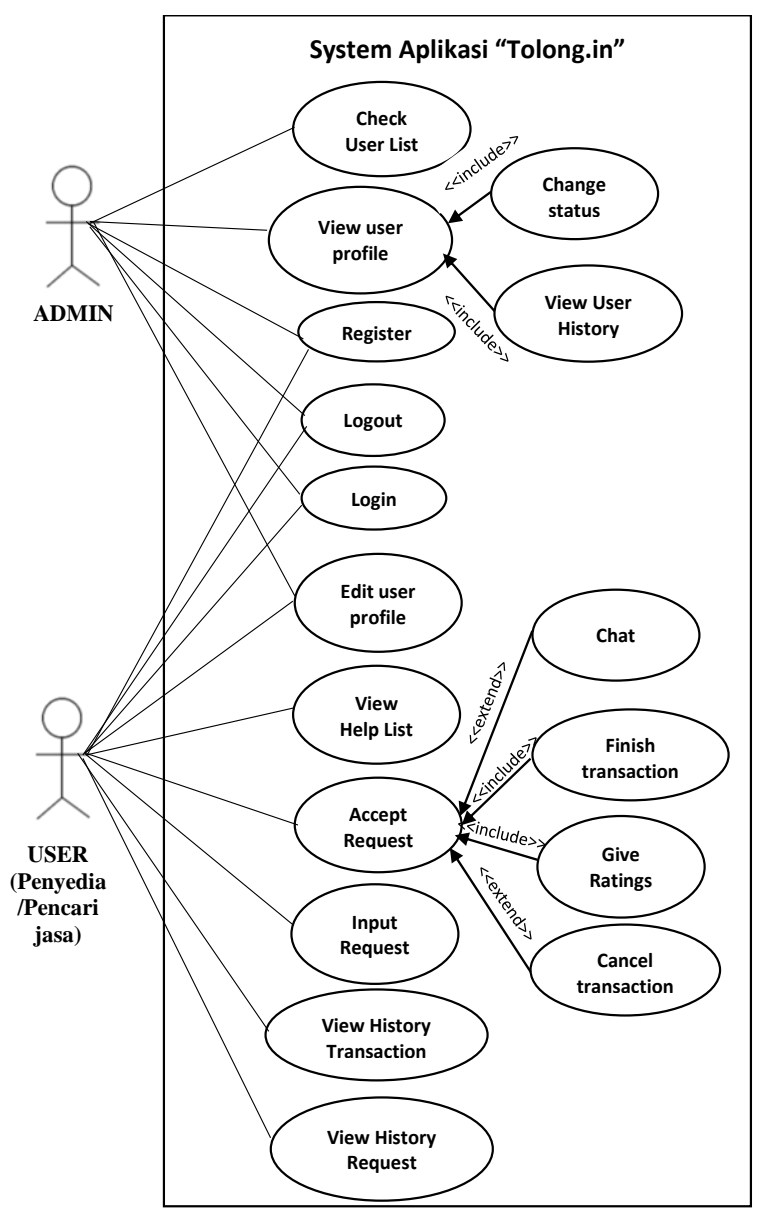

Gambar 2. Use Case Diagram aplikasi “Tolong.in”

Berdasarkan use case diagram yang dapat dilihat pada Gambar 2, terdapat 2 role yang dapat mengakses aplikasi, yaitu admin dan user. Di mana user dapat bertindak baik sebagai penyedia jasa maupun sebagai penerima jasa. Fitur yang dapat diakses oleh kedua role (admin dan user) yaitu:

(1) Login

Semua pengguna aplikasi ini harus melakukan login ke dalam aplikasi jika ingin mengakses fitur-fitur yang ada dalam aplikasi

Sedangkan fitur yang bisa diakses oleh role user adalah :

(1) Input request

Fitur ini digunakan jika user bertindak sebagai pencari jasa dan sedang membutuhkan jasa seseorang. Pada menu input request ini, user sebagai pencari jasa menginput informasi mengenai jasa apa yang ia perlukan serta pin lokasi user membutuhkan pertolongan

(2) View Request List dan Accept request Seperti yang telah dijelaskan sebelumnya bahwa user aplikasi tolong.in ini dapat bertindak juga sebagai penyedia jasa. Jika user bertindak sebagai penyedia jasa, user 
dapat melihat list user lain yang membutuhkan pertolongan dan dari list tersebut user dapat memilih siapa yang akan menjadi customernya. List kebutuhan jasa yang muncul pada request list user divalidasi untuk sesuai dengan keahlian yang diinputkan ke dalam aplikasi pada saat melakukan registrasi. Setelah transaksi selesai, user sebagai penyedia jasa bisa melakukan finish transaksi.

(3) Fitur chat

Selama terjadinya transaksi, aplikasi tolong.in juga memberikan fasilitas chat yang dapat memudahkan sang penyedia jasa dan pencari jasa untuk saling berkomunikasi.

(4) Give rating

Setelah transaksi selesai, user sebagai pencari jasa diminta untuk memberikan rating terhadap jasa yang baru dipakainya. Rating ini akan digunakan sebagai bahan evaluasi apakah sang penyedia jasa tersebut dapat dipercaya atau tidak. Jika rating penyedia jasa $\leqslant 3$ maka penyedia jasa tersebut akan terkena banned untuk sementara waktu

(5) View history transaction dan view history request

History transaksi user sebagai penyedia jasa dan history list request jasa user sebagai pencari jasa dapat dilihat di menu view history transaction dan view history request.

(6) Edit profile

User juga dapat mengedit data dirinya pada menu edit profile.

Fitur-fitur yang dapat diakses oleh role admin adalah :

(1) Check user list

Pada menu ini, admin dapat melihat semua list pengguna yang terdaftar pada aplikasi tolong.in

(2) View user profile dan change status Pada menu ini, admin dapat melihat dengan detail data diri dari masingmasing user. Jika terdapat user yang terkena banned sehingga user tersebut tidak dapat menawarkan jasanya lagi menggunakan aplikasi tolong.in, admin akan melakukan verifikasi secara manual terhadap user tersebut dan admin juga dapat mengubah statusnya kembali melalui menu change status

\subsection{Class Diagram}

Class diagram aplikasi tolong.in dapat dilihat pada Gambar 3.

\section{HASIL DAN PEMBAHASAN}

\subsection{Tampilan Aplikasi}

Berikut ini adalah tampilan menu register dari aplikasi tolong.in. Menu register ini juga sudah dilengkapi oleh validasi input, untuk mencegah kesalahan input data

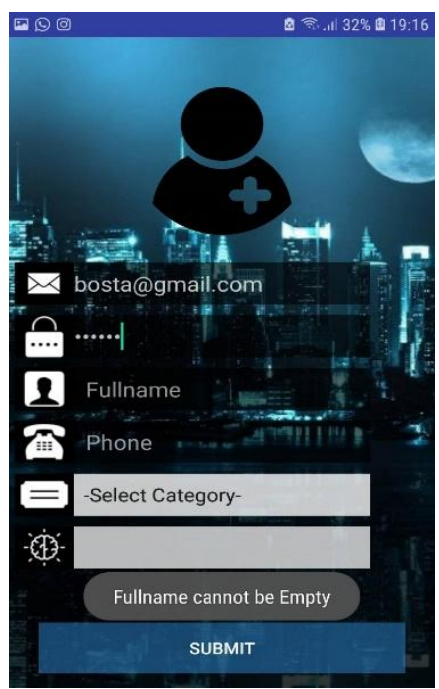

Gambar 4. Menu Register pada aplikasi tolong.in

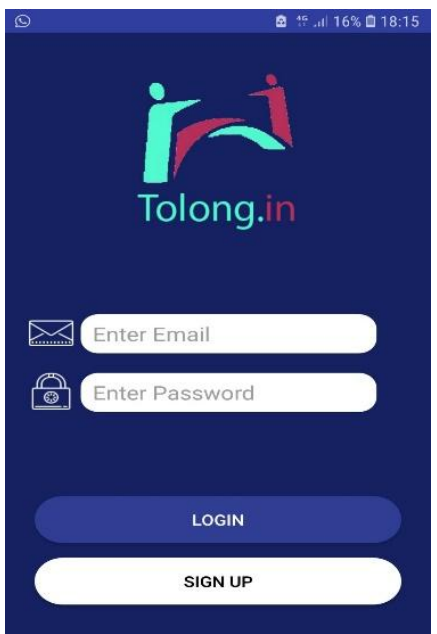

Gambar 5. Menu login aplikasi tolong.in

Untuk dapat mengakses semua fitur pada aplikasi tolong.in, semua user harus melakukan login. Gambar 4 menunjukkan tampilan menu login yang ada pada aplikasi tolong.in. Jika user sudah berhasil login atau melakukan registrasi, maka user akan langsung diarahkan ke menu/halaman view help list yang berisi list user lain yang membutuhkan jasa yang keahliannya dimiliki oleh user tersebut. Jika user menyanggupi memberikan jasanya maka user hanya perlu menekan tombol help. 


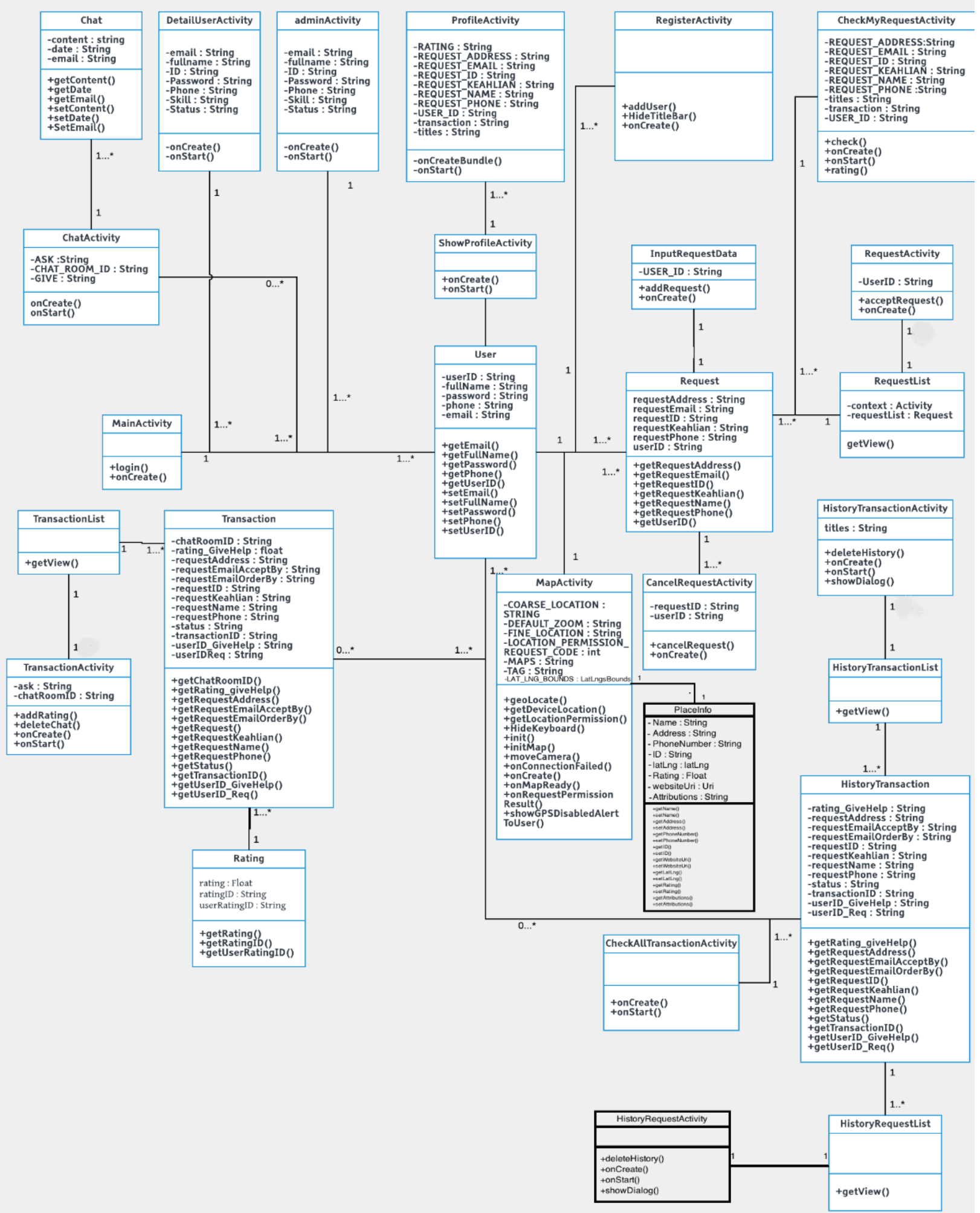

Gambar 3. Class Diagram Aplikasi “Tolong.in” 


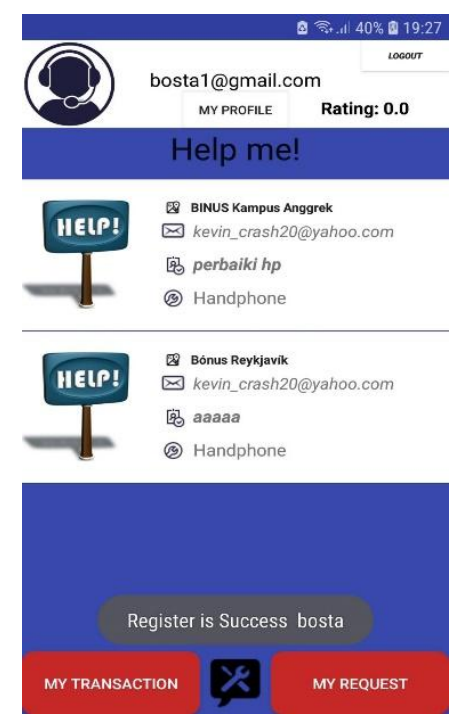

Gambar 6. Menu View Help List pada aplikasi tolong.in

User yang sama juga bisa bertindak sebagai pencari jasa dengan menginputkan jasa yang dibutuhkan pada menu Input Request yang ditunjukkan oleh Gambar 7

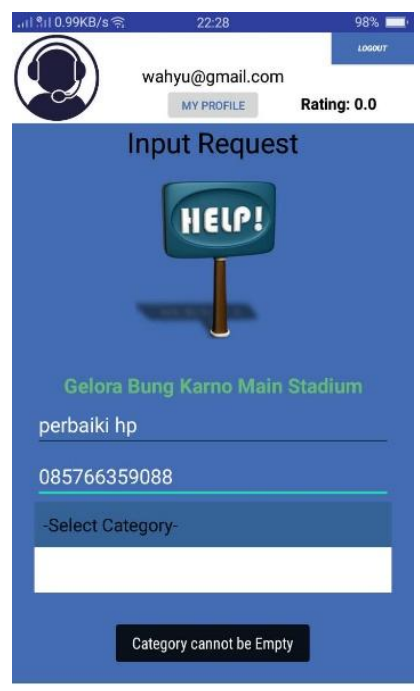

ADD REQUEST

Gambar 7. Menu Input Request pada aplikasi tolong.in

Penyedia jasa dan pencari jasa juga dapat berkomunikasi melalui fasilitas chat yang ada pada aplikasi tolong.in yang ditunjukkan pada Gambar 8

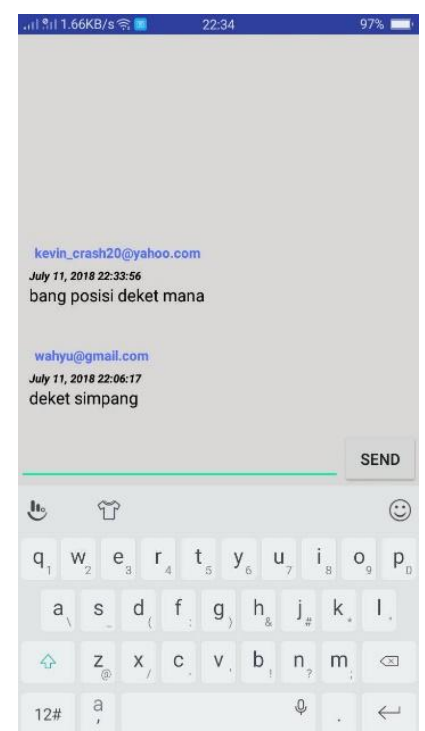

Gambar 8. Fitur chat pada aplikasi tolong.in

Setelah transaksi selesai, pencari saja akan diminta untuk memberikan rating terhadap penyedia jasa yang ia gunakan jasanya. Menu pemberian rating dapat dilihat pada Gambar 9

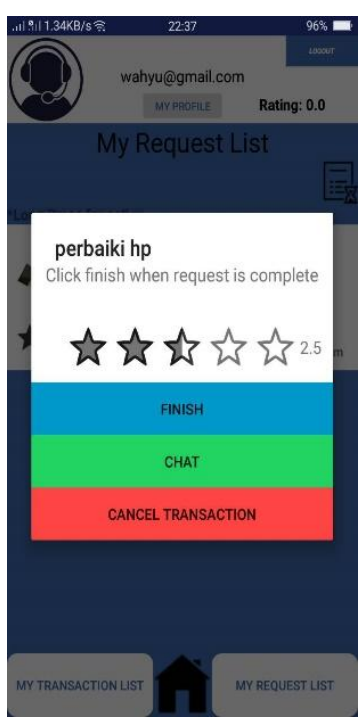

Gambar 9. Menu Finish transaction dan give rating

Semua history request jasa dan history transaksi penyedia jasa dapat dilihat di menu History Request List dan My History Transaction. Menu My History Transaction dapat dilihat pada Gambar 10. 


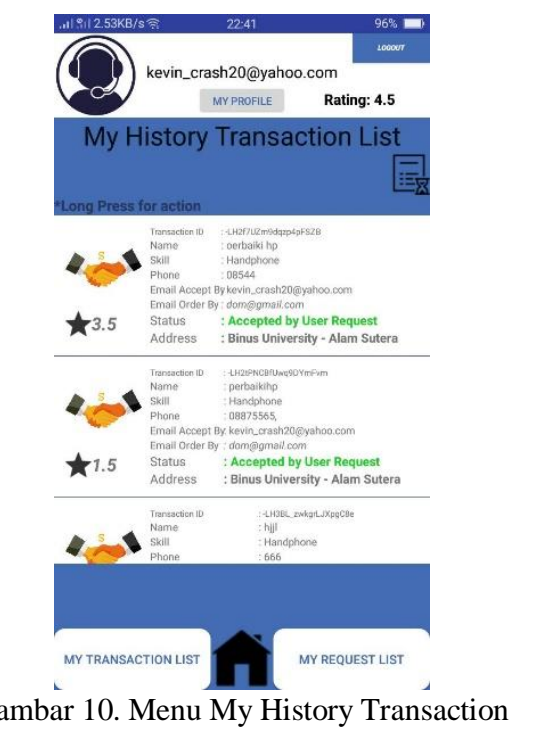

\subsection{Evaluasi Aplikasi}

Antar muka aplikasi dievaluasi dengan menggunakan 5 faktor manusia terukur (Shneiderman, 2010) yang divalidasi dengan kuesioner yang diisi oleh 50 pengguna aplikasi tolong.in untuk memastikan bahwa antara muka yang dibuat mudah dimengerti dan digunakan oleh pengguna. Berdasarkan hasil evaluasi dan kuesioner didapatkan bahwa $70 \%$ dari pengguna menyatakan bahwa aplikasi tolong.in mudah untuk dimengerti dan dipelajari (Time to learn). Kemudian dari segi performa, sekitar 96\% pengguna setuju bahwa performa aplikasi sudah sangat baik dan mudah untuk digunakan (speed of performance dan rate error by user). Sekitar $96 \%$ pengguna juga menyatakan bahwa aplikasi tolong.in memiliki antar muka yang sederhana sehingga memudahkan user untuk memahami dan mempertahankan daya ingat mereka selama penggunaan aplikasi (time of retention). Akhirnya 97\% pengguna merasa puas dengan aplikasi tolong.in (subjective satisfaction). Para pengguna merasa aplikasi tolong.in membantu mereka untuk memasarkan jasa/keahlian mereka dan juga membantu mereka untuk mencari jasa yang mereka butuhkan.

\section{KESIMPULAN}

Berdasarkan hasil dari pembuatan aplikasi berbasis android "Tolong.in" dan hasil dari kuesioner penggunaan aplikasi" maka didapatkan kesimpulan sebagai berikut :

(1) Perancangan dan pengembangan aplikasi "Tolong.in" dapat membantu user mendapatkan informasi mengenai penyedia jasa yang dibutuhkan oleh user
(2) Aplikasi “Tolong.in" dapat membantu penyedia jasa untuk memasarkan jasa mereka

(3) Aplikasi 'Tolong.in" dapat memudahkan komunikasi antara penyedia jasa dan pencari jasa dengan adanya fitur chat dan teknologi GPS

(4) Melalui aplikasi "Tolong.in" transaksi jasa dapat dijalankan dengan aman dengan adanya sistem pemberian rating pada penyedia jasa setiap berakhirnya suatu transaksi.

\section{DAFTAR PUSTAKA}

Almuzakki, M. A. (2013). Rancang Bangun Aplikasi Location-Based Service Pencarian Lokasi Wisata di Kota Semarang Berbasis Android. Semarang : Universitas Dian Nuswantoro Semarang.

B. R. Rompas, A. A. (2012). Aplikasi Location-based Service Pencarian Tempat di Kota Manado Berbasis Android. journal Teknik Elektro dan Komputer, 1(2), 1-11.

Baron, R. A. (2006 ). Social psychology. Boston : Aufl.

Buulolo, E. (2013). IMPLEMENTASI ALGORITMA STRING MATCHING DALAM PENCARIAN SURAT DAN AYAT DALAM BIBLE BERBASIS ANDROID. Pelita Informatika Budi Darma, 3, 23-27.

Shneiderman, B. (2010). Designing the user interface: strategies for effective humancomputer interaction. India: Pearson Education.

Wishnu. (2012). Aplikasi terbaik HP \& tablet : GPS pada android / Wishnu E.W. Jakarta: Jasakom.

Yulianto, B. (2010). Teknologi Location Based Service (Global Positioning System) Pada Perangkat Mobile. Comtect Stats, 1, No.1, 